\title{
Racial health disparities in ovarian cancer: not just black and white
}

\author{
Sanjeev K. Srivastava ${ }^{1,2^{*}+}$, Aamir Ahmad ${ }^{1 \dagger}$, Orlandric Miree ${ }^{1}$, Girijesh Kumar Patel ${ }^{1}$, Seema Singh ${ }^{1,3}$, \\ Rodney P. Rocconi ${ }^{4}$ and Ajay P. Singh ${ }^{1,3^{*}}$
}

\begin{abstract}
Ovarian cancer (OC) is the most lethal gynecological malignancy, which disproportionately affects African American (AA) women. Lack of awareness and socioeconomic factors are considered important players in OC racial health disparity, while at the same time, some recent studies have brought focus on the genetic basis of disparity as well. Differential polymorphisms, mutations and expressions of genes have been reported in OC patients of diverse racial and ethnic backgrounds. Combined, it appears that neither genetic nor the socioeconomic factors alone might explain the observed racially disparate health outcomes among OC patients. Rather, a more logical explanation would be the one that takes into consideration the combination and/or the interplay of these factors, perhaps even including some environmental ones. Hence, in this article, we attempt to review the available information on OC racial health disparity, and provide an overview of socioeconomic, environmental and genetic factors, as well as the epigenetic changes that can act as a liaison between the three. A better understanding of these underlying causes will help further research on effective cancer management among diverse patient population and ultimately narrow health disparity gaps.
\end{abstract}

Keywords: Ovarian cancer, Racial health disparity, Socioeconomic, Epigenetic

\section{Background}

Ovarian cancer $(\mathrm{OC})$ is the most lethal of all gynecologic malignancies [1]. Globally, $\mathrm{OC}$ is the 7 th most commonly diagnosed and the 8th leading cause of cancer-related mortality among women [2]. According to estimates by the American Cancer Society, 22,440 new OC cases and 14,080 associated deaths will occur in 2017 [1]. It is a deadly disease with no effective screening [3]. Approximately 70\% of patients with $\mathrm{OC}$ are diagnosed at an advanced stage, with associated poor prognosis, even after aggressive and immediate treatments [4]. Studies over past several years have revealed that besides being highly lethal, OC also disproportionately affects some distinct racial populations, particularly the black women of African American (AA) heritage, as compared to the Caucasian Americans (CA) or white

\footnotetext{
* Correspondence: ssrivastava@health.southalabama.edu;

asingh@health.southalabama.edu

${ }^{\dagger}$ Equal contributors

1 Department of Oncologic Sciences, Mitchell Cancer Institute, University of

South Alabama, 1660 Springhill Avenue, Mobile, AL 36604-1405, USA

Full list of author information is available at the end of the article
}

women of European heritage. In fact, even with higher incidence of $\mathrm{OC}$ in CA women in the United States, the associated mortality is disproportionately higher in AA women [5], and such disparities are common worldwide [6]. Though the exact causes of racial disparities in OC still remain unclear, they are likely to be multifaceted and may include sociocultural factors, acquired co-morbid conditions, increased frequency of modifiable risk factors, access to health care, diet and preventive health factors. Emerging data suggests that several biological factors, such as genetic, epigenetic etc., could be more crucial than thought for health disparities in OC incidence and outcome $[5,7,8]$. In this review article, we have discussed, in-detail, various biological and non-biological factors in racially disparate clinical outcomes of OC.

\section{Disparity in ovarian cancer incidence and mortality}

While some progress has been made in OC treatment, it has been observed that AA women with $\mathrm{OC}$ are not 
reaping the same benefits of the advances as CA women. Progress in management of $\mathrm{OC}$ patients has improved over time but this progress has been relatively slow for AAs [9]. The all-cause mortality of AA OC patients is 1.3 times higher, as compared to CA OC patients, even when access to care is equal [5]. According to data from SEER database, between the years 1992 and 2008, the five-year survival rate for CA women rose from $40.7 \%$ to $45.0 \%$, while the five-year survival for AA women fell from $47.9 \%$ to $40.3 \%$. For the years 2006 through 2012, the reported 5 year survival of AA OC patients is relatively poor, compared to CA OC patients, irrespective of cancer stage at the time of diagnosis [1] (Table 1). Although the overwhelming majority of all OC patients are diagnosed at an advanced stage, it has been suggested that AA women bear a greater burden in the late diagnosis than $\mathrm{CA}$ women. Increased instances of late diagnosis may be attributed to socio-economic factors that will be discussed later in this article.

This disparity in survival may also be linked to observed prevalence of comorbidities. Evidence shows that AA women diagnosed with $\mathrm{OC}$ are much likely to have hypertension (75.5\%), renal disease (58.5\%) and cardiovascular disease (63.21\%) [10]. Often, AA women, post-treatment, tend to have elevated CA-125 levels [10]. CA-125 is a diagnostic marker for $\mathrm{OC}$ and its elevated levels indicate a lingering $\mathrm{OC}$, which could implicate higher recurrence and, possibly, reduced survival. Further, earlier normalization of CA-125 levels during primary chemotherapy for epithelial OC predicts improves progression free survival (PFS), overall survival (OS) as well as platinum sensitivity [11]. For each one-cycle improvement in CA-125 normalization, there is an estimated 3.8 months increase in PFS, 8.6 months increase in OS and $8 \%$ increase in platinum sensitivity.

With the realization of race-based OC health disparities [12], efforts are now being made to better understand the etiology and progression of $\mathrm{OC}$ in AA populations. For example, a recent study looked at the lifetime number of ovulatory cycles and epithelial OC risk in just AA patients [13]. The study found a positive association between lifetime ovulatory cycles and epithelial $\mathrm{OC}$ in $\mathrm{AA}$ women, similar to what was already known in CA patients. The association of antioxidant

Table 1 Five-year relative survival rates of ovarian cancer patients in United States, by stage at the time of diagnosis

\begin{tabular}{llll}
\hline Diagnosis stage & African American & Caucasian American & All races \\
\hline Localized & 86 & 93 & 92 \\
Regional & 58 & 73 & 73 \\
Distant & 21 & 29 & 28 \\
All stages & 36 & 46 & 45 \\
\hline
\end{tabular}

The data is for years 2006 through 2012 [1] selenium uptake and risk of $\mathrm{OC}$ in AA women was also studied in a cohort of 406 AA OC patients and 632 AA healthy (control) women that were age- and sitematched [14]. Consistent with the beneficial effects of antioxidants, women with high selenium intakes were found to be at $\sim 30 \%$ lowered risk of OC. Further, oral contraceptive use, pregnancy and breastfeeding were observed to be inversely correlated with $\mathrm{OC}$ in AA women, similar to what was already known in CA women [15]. Also, high intake of dietary sugars and glycemic load were confirmed to be associated with higher OC risk in AA women, similar to other populations [16].

\section{Socioeconomic and other factors contributing to racial health disparities in ovarian cancer}

Socioeconomic status (SES) remains a major factor driving OC health disparities. In a study that evaluated 2432 epithelial OC patients (1989 CA vs. 443 AA) in Cook County, Illinois between the years 1998 and 2007, neighborhood SES, particularly the affluence and disadvantage, had profound effect on OC survival [17]. Even after adjusting for factors such as age, tumor characteristics, treatment and year of diagnosis, AAs were much more likely to succumb to OC, compared to CAs. This disparity could be attenuated only if SES factors were factoredin as well. On very similar lines, in a study that evaluated patients from the same locality, but from an early timeperiod (1994 through 1998), neighborhood disadvantage was still observed as the primary reason for OC-specific survival [18]. In an earlier report [19], AA OC patients were reported to be less likely to undergo surgery and chemotherapy. Unfortunately, the $\mathrm{OC}$ health disparity has increased over time and one reason for this increase is the disparate access to treatment, particularly surgery [20]. In a study that evaluated $393 \mathrm{OC}$ patients (68 AA vs. $325 \mathrm{CA}$ ), a clear survival disadvantage was observed in AA patients [21]. The AA patients had lower SES, in terms of education, income and property, to start with. However, the survival disadvantage was evident even when controlled for these factors. Progression free survival was only 16 months in AA OC patients, as compared to 27 months in CA OC patients, whereas overall survival was less than half in AA patients (42 months), as compared to CA patients (88 months).

Racial disparity has been noted in the diagnosis of OC [22] with AA women being frequently diagnosed with advanced stage OC. However, interestingly, in one study, no race-based differences in clinical outcome were reported in patients with advanced stage epithelial OC, provided they received similar treatment [23]. While elsewhere, it has also been reported that AA OC patients are much less likely to receive standard guidelinerecommended care, as compared to CA patients [24]. Although these studies seem to support the notion that 
equal access to healthcare is an important factor in determining disparate $\mathrm{OC}$ outcomes, it is also possible that this was because of the fact that these studies focused on advanced stage OCs, where the disease was too progressed and aggressive in the patient populations to reveal a meaningful correlation of progression and/or survival with the race. Access to healthcare has often been discussed as an important factor that influences cancer health disparity. In OC, access to health care and its impact on survival of OC patients was studied in a cohort study in Northern California [10]. Since the cohort comprised of members of Kaiser Permanente, it was assumed that the access to health care was uniform for all subjects. Even with equivalent access to health care, AA women had worst survival, which was, in part, due to treatment delay and early discontinuation.

Geographical proximity to a tertiary hospital system and travel distance are also factors that play a role in disparate outcome of OC in AA women [25]. Availability of reliable mode of transportation is part of the SES, and it is believed that AA OC patients are much less likely to travel more than 20 miles to a big hospital for treatment, compared to CA patients. While $\sim 22 \%$ CA patients would travel more than 20 miles for treatment, only about $14 \%$ AA patients would likely travel this distance. This results in increased risk of non-adherent care and the resulting sub-optimal treatment and follow-up. AA patients are also significantly less likely to undergo initial surgical intervention for $\mathrm{OC}$ at big, high-volume hospitals, compared to CA patients [26]. Participation of minorities in clinical trials is yet another challenge. It has been reported that the overall enrollment of AA populations in gynecologic oncologic group (GOG) trials is dismal, and is probably going down further, according to the most recent data [8]. In this data, generated from 445 GOG publications between 1985 and 2013, the overall participation of AA patients was just $8 \%$, compared to $83 \%$ CA patients. The more disturbing observation was that the situation is probably getting worse as the enrolment of AA patients has gone down 2.8 folds for the years 2009-2013, compared to the enrolment in years 1994 through 2002. The various non-biological factors that contribute to $\mathrm{OC}$ health disparities, as discussed in this section above, are summarized in Fig. 1.

\section{Biological basis of ovarian cancer health disparities}

While non-biological factors play an important role in OC health disparity, there is evidence to suggest a critical role of biological factors in OC health disparity as well [6]. In fact, enhanced incidence and mortality in AA women with $\mathrm{OC}$ has been observed, as compared to EA counterparts, even when socioeconomic factors have been accounted for. For example, in a study that evaluated 393 OC patients (68 AA vs. $325 \mathrm{CA}$ ), a clear survival disadvantage was observed in AA patients [21]. The AA patients had lower SES, in terms of education, income and property, to start with. However, the survival disadvantage was evident even when controlled for these factors. Progression

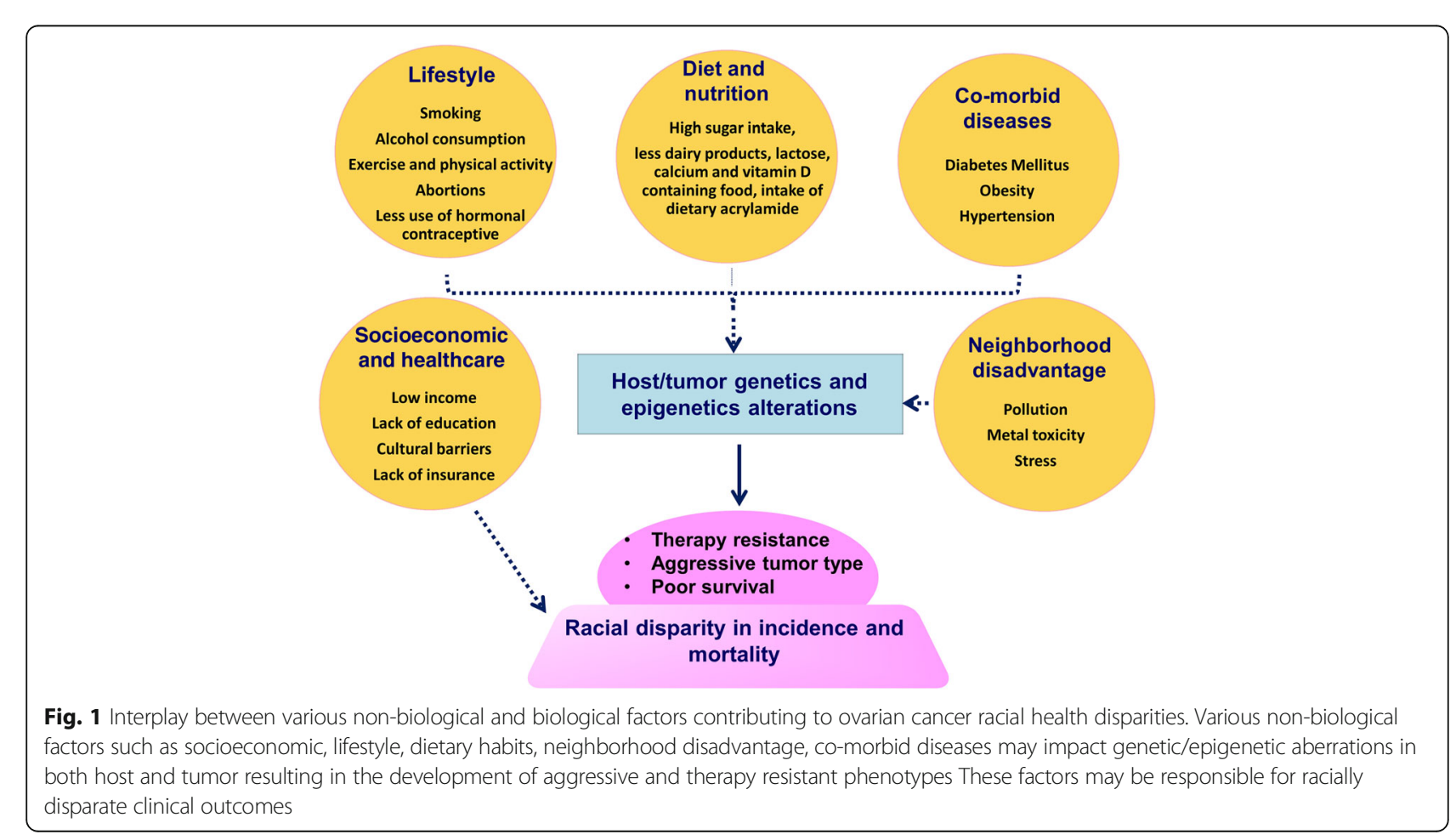


free survival was only 16 months in AA OC patients, as compared to 27 months in CA OC patients, whereas overall survival was less than half in AA patients (42 months), as compared to CA patients (88 months). Possible involvement of biological factors in $\mathrm{OC}$ health disparity was also suggested in a study that factored for access to healthcare, and still observed poor survival of AA OC patients, compared to CA patients [10].

Higher adiposity is a known OC risk [27]. Since AA women have disproportionately high rate of obesity [28], a study was carried out to evaluate whether body mass index (BMI) or the weight gain since the age of 18 years can be independent OC risk factors [27]. It was observed that a $\mathrm{BMI} \geq 40$ posed a significant $\mathrm{OC}$ risk, compared to $\mathrm{BMI}<25$, thus connecting obesity with increased OC risk. Similarly, gain of weight since age 18 also correlated positively with OC risk [27]. In a similar study, where BMI $\geq 30$ was considered obese, AA women with higher BMI reported having OC symptoms much before the formal diagnosis [29]. Severe obesity is a critical risk factor for OC [30], underlining the importance of healthy and active lifestyle.

Several molecular alterations such as gene-mutations, genetic polymorphism, epigenetic alterations etc. have been associated with $\mathrm{OC}$ racial health disparities (Fig. 2). In this section we discuss the role of these molecular factors in the racially disparate outcome of OC.

\section{Genetic factors associated with ovarian cancer health disparities}

The underlying causes for $\mathrm{OC}$ health disparities are complex; they are clearly a mixture of biological as well as non-biological factors [31]. Phosphoserine phosphatase like (PSPHL) expression is elevated in AAs, compared to CAs [32]. PSPHL was primarily identified as a differentially over-expressed gene in AA endometrial cancers, relative to CA endometrial cancers. Since both ovarian and endometrial cancers belong to the family of gynecological cancers, the study was extended to evaluate PSPHL expression in AA vs. CA OCs as well. Similar to endometrial cancers, PSPHL was found to be elevated in AA OCs, as compared to CA OCs. Interestingly, PSPHL levels are relatively higher in AA breast tumors than the CA breast tumors [33]. Health disparities in breast cancer are well documented $[34,35]$ and the study on PSPHL in breast tumors [33] identified partial deletion (30Kb long fragment) of chromosome 7p11 in CA women, which led to attenuation of expression of PSPHL in CA breast tumors. No such mechanism was proposed for observed disparate expression of PSPHL in OCs of AA vs. CA origin, and would be interesting to elucidate.

AA women are at relatively higher risk of $O C$ because of higher rates of BRCA1 and BRCA2 mutations, as compared to other racial/ethnic populations [36, 37]. This represents an interesting evolution in our understanding of BRCA mutations in AA women because early studies on the subject seemed to suggest the opposite; that AA women harbor significantly less BRCA mutations, compared to CA women [3]. BRCA1 and BRCA2 are tumor suppressors that play a role in repair of damaged DNA. Inherited mutations in BRCA1 and BRCA2 often result in breast and/or OC. It has been estimated that the patients with BRCA1 mutations have $39 \%$ while those with BRCA2 mutations have $11 \%$ risk of developing OC by an age of 70 years [38].

The connection between inflammation and cancer is well known [39], and, recently, it has been suggested that pro-inflammatory diet leads to increased risk of epithelial $\mathrm{OC}$ in AA women [40]. The study calculated 'dietary inflammatory index' through a questionnaire that focused on dietary intake in the year prior to diagnosis of OC [40]. Women that consumed the most pro-inflammatory diet were at significantly higher risk of epithelial OC. Inflammation is known to play a role in $\mathrm{OC}$ onset and progression [41]. The pro-inflammatory cytokines produced within the tumor microenvironment help ovarian tumors proliferate as well as evade chemotherapy [42].

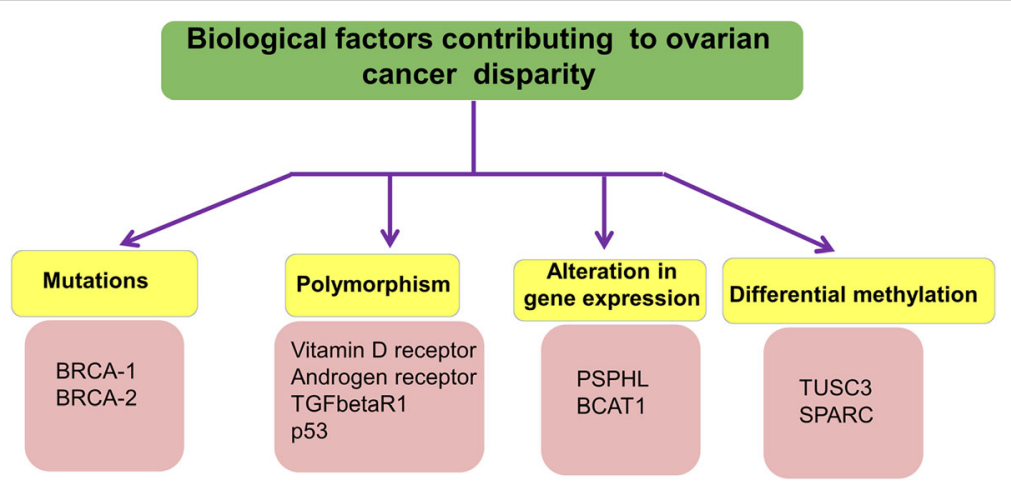

Fig. 2 Biological factors associated with ovarian cancer racial health disparities. Mutations, genetic polymorphisms, epigenetic alterations and aberrant gene expressions play important role in ovarian cancer health disparities 
Studies document that high intake of carbohydrate-rich foods may result in the production of IGF-1 that is known to promote ovarian tumorigenesis via stimulation of hormones such as androgens. Moreover, alterations in glucose levels could induce oxidative DNA damage [16]. Analgesic medications also seem to play a role in OC risk. AA women taking aspirin for prevention of cardiovascular diseases or the non-aspirin nonsteroidal anti-inflammatory drugs for arthritis had $44 \%$ and $26 \%$ lower risk of epithelial OC, respectively [43].

Vitamin D is another factor that is increasingly being correlated with cancer health disparities [44]. The darker skin pigmentation in AA populations results in significantly lower serum vitamin D levels, and since vitamin D levels inversely correlate with multiple cancers [44], lower serum vitamin D levels are observed in patients diagnosed with different cancers, including OC. It has been suggested that daily intake of vitamin $\mathrm{D}$, along with calcium, can reduce the cancer risk in women by $60 \%$ [45]. Further, for every $10 \mathrm{ng} / \mathrm{mL}$ increase in the levels of vitamin $\mathrm{D}$, the cancer risk decreases by 35\% [45]. As a direct connection between $\mathrm{OC}$ and vitamin $\mathrm{D}$, it has been reported that $\mathrm{OC}$ patients are four times more likely to have lower serum vitamin D levels, as compared to healthy controls [46]. Studies have shown that vitamin D inhibits cancer cell proliferation by inducing cell cycle arrest at G1 phase via up-regulation of expression of CDKIs p21WAF 1/ Cip 1 and p27Kip [47]. A vitamin D response element is also known to be present in the promoter region of p21 gene, suggesting that vitamin $\mathrm{D}$ may directly cause the transcriptional activation of p21 [48].

Gene polymorphisms have also been implicated in disparate OC in AA women. Vitamin D receptor polymorphism, particularly at a minor allele rs7975232, has been linked to higher risk of epithelial OC in AA women [49]. SNP rs7305032, in close proximity to this allele, correlated with nearly two-folds increased risk of invasive epithelial OC in AA women [49]. Similarly, CAG repeat length polymorphism in exon 1 of androgen receptor gene was observed to increase risk of $\mathrm{OC}$ in AA, with, interestingly, no such correlation in CA [50]. In one of the earliest studies on the topic, racially disparate polymorphism of tumor suppressor gene p53 was suggested [51]. Codon 72 of p53 gene has arginine and proline allelotypes. The arginine allelotype is more frequent in CAs while the proline allelotype is more frequent in AAs [51]. In a study that evaluated the $6 \mathrm{~A}$ allele of type I transforming growth factor beta receptor 1 (TGF $\beta R 1$ ), no increased OC risk was associated with the allele [52]. However, significant racial differences in the frequency of this allele were observed, with the allele being relatively infrequent in AA women (2.4\%), compared to CA women (10.7\%). A more thorough study would be needed to better understand the link between this TGF $\beta$ R1 allele and racial disparity in OC.

\section{Epigenetic changes in ovarian cancer health disparities}

Epigenetic changes are known to function as liaisons between socioeconomic factors and the genome; they keep accumulating and affecting the epigenome in various racial/ethnic groups, resulting in disparate and poor cancer outcomes [35]. A functional role of epigenetic changes in aggressive high-grade serous $\mathrm{OC}$ has been described, leading to resistance against platinum-containing chemotherapy [53]. AA OCs are much more aggressive, and associated with poor overall survival, compared to CA OCs. This suggests the possibility of epigenetic modifications as factors that play a role in OC health disparity, an idea that has not yet been tested.

As mentioned above, endometrial cancers and OCs belong to the same family of gynecological cancers. Incidentally, there is evidence in the literature suggesting an epigenetic basis of health disparity in endometrial cancers [35], particularly, differential ribosomal DNA methylation in AA vs. CA patients [54]. This raises the hope that the differential methylation, as observed in drug-resistant OCs [53] might also be relevant in OC health disparity. This speculation is further fueled by some indirect evidences that link epigenetically-regulated genes in $\mathrm{OC}$ with health disparities in other cancers. For example, methylation of TUSC3 (tumor suppressor candidate 3) [55] has been linked to poor disease-free survival of OC patients. TUSC3 was part of a gene signature evaluated for differential methylation and expression in AA vs. non-CA breast tumors [56]. Further, silencing of SPARC, through hypermethylation, has been reported in OC [57]. This gene was part of a signature that was investigated for putative role in prostate cancer health disparity. SPARC has been reported to be frequently down-regulated in cancer cells [58]. It is silenced through promoter methylation in metastatic and aggressive cancer cells [59]. Finally, BCAT1 (branched chain amino-acid transaminase 1) is reportedly over-expressed in ovarian tumors [60], possibly through a mechanism involving hypomethylation [61]. BCAT1 was one of the top up-regulated genes in AA colorectal cancer patients-derived samples, as compared to samples from CA colorectal cancer patients. In light of these observations, it might be worthwhile to evaluate these genes, as a starting point, for their potential disparate expression and a role in OC health disparity.

Regulation of gene expression by differential methylation is a classic example of epigenetic event. However, regulation of genes through miRNAs is also within the broader definition of epigenetic changes. A number of miRNAs have been reported deregulated in OC models with potential role as diagnostic and/or prognostic markers [62]. Also, miR-152 has been shown to regulate DNMT1 (DNA methyltransferase-1) [63], an enzyme that actively influences the overall methylation status by transferring methyl groups to its targets. miR-152 is also 
linked to cancer health disparity as it was significantly down-regulated in about $\sim 50 \%$ of AA prostate cancer tissues, compared to $35 \%$ of CA samples [64].

\section{Interplay of genetic and environmental factors in ovarian cancer and associated health disparities}

Environmental factors influence genetic factors, and such interactions lead to onset of human cancers. Risk of OC has been linked to several environmental factors $[65,66]$. Although occupational exposures and environmental factors seem to correlate with increased OC risk, epidemiological analyses have often failed to establish a positive link $[67,68]$. This has been blamed on cohort size, statistical power and several other factors.

One environmental factor that has been linked to increased OC risk is the use of pesticides and herbicides [66]. This is particularly concerning in developing countries where stable organochlorine pesticides represent a bulk of pesticides in use [69]. These pesticides persist in environmental because they are not easily biodegradable and the half-lives run in decades. Their carcinogenic activity is related to estrogen-mimicking property [69]. While indiscriminate use of such harmful compounds is relatively more prevalent in underdeveloped and developing countries, even the developed countries are not immune to this environmental risk of OC. For example, in the US, pesticide atrazine has been detected in public water supplies in Iowa [70]. It is documented that atrazine causes phosphorylation of ERK and induces expression of oncogenes such as cyclin A, progesterone receptors, c-fos etc. to promote the proliferation of cancer cells [71]. Levels of nitrates in the drinking water were linked to an increase in OC risk, especially among the post-menopausal women, in the Iowa Health Women's study [72]. CYP2E1 gene mutation is reported to be associated with cytotoxicity and DNA damage as a result of nitrosamines [73]. Based on this, it could be speculated that there may be an association between high nitrate containing drinking water and genetic variation in CYP2E1, which may present increased risk of $\mathrm{OC}$ in AA women.

Talc, consisting of magnesium silicate, is another environmental factor with possible carcinogenic implications. The association between talc (talcum) and OC has been controversial, and a subject of legal battles [74]. When applied to genital areas, diaphragms or sanitary napkins, it can possibly cause OC. A pooled analysis of 8525 patients observed a moderate risk of OC in patients with reported genital powder use [75], with positive correlation between powder use and elevated risk of individual OC subtypes. A prospective study that followed 61,576 post-menopausal women for 12.4 years, however, could not link talc use with OC risk [76]. The results were confirmed by another independent study which found douching, and not talc use, as a risk factor for OC [77]. A recent meta-analysis, however, confirmed risk of $\mathrm{OC}$ from genital talc use with a statistically significant risk of serous OC [78]. It has been suggested that the risk of $\mathrm{OC}$ from genital talc use is rather complex, and involves many considerations, such as menopause status, hormone therapy, weight, smoking etc. [79]. Harmful effects of talc include elevated immunoglobulins and heat shock proteins [80]. In a gene-talc interactions study performed in $\mathrm{OC}$, it was observed that women exhibiting specific genetic polymorphism in GSTM1 and GSTT1 may have a higher risk of serous invasive OC, associated with genital talc use [81]. Functional role of GSTM1 and GSTT1 in the metabolism of carcinogens and reactive oxygen species has been reported [82]. Thus, although, environmental factors have been suggested to influence $\mathrm{OC}$, and even confirmed by a few analyses, the topic remains controversial with individual analyses marked by limitations that prevent an objective assessment and a definite conclusion. While designing future studies, it would also be interesting to evaluate the role of several environmental risk factors in $\mathrm{OC}$ cancer health disparities.

\section{Conclusions and perspectives}

The existence of $\mathrm{OC}$ health disparities is undeniable, as per the evidence that has accumulated over last decade or so. For records, it needs to be acknowledged that it's not just the AA women, but $\mathrm{OC}$ health disparities are evident in other populations as well, such as, Hispanics and Asian/Pacific Islanders [10, 26, 83]. What is not clearly understood is the basis of such disparities. Nonbiological factors, particularly the socioeconomic ones, make sense but emerging literature clearly hints at existence of defining biological factors as well. While non-biological factors might appear to be simple and straight-forward, a closer look reveals that OC health disparities involving SES factors such as neighborhoodrelated, income, access and affordability of treatment etc. are not easy to be addressed. A number of steps need to be taken to tackle these issues [84]. These will invariably involve some grass-root level efforts with involvement of community outreach programs, counseling initiatives and, possibly, social media. The establishment of partnerships such as Georgia Breast Cancer Genomics Health Consortium to assist young AA women at increased risk of hereditary breast and $\mathrm{OC}$ is a step in this direction [85]. In addition to the various nonbiological and biological bases of $\mathrm{OC}$ health disparities, there is an added burden of factors that are difficult to classify one way or the another. An example is the suggestion that more prevalent use of genital powder in AA women is a risk factor for epithelial OC [86]. Thus, an interplay of biological as well as non-biological 
factors, with some role of environmental factors, is possibly a more acceptable explanation for observed OC health disparities. This brings in epigenetic factors that provide a logical connection between biological, nonbiological as well as environmental factors. When compared to other cancers with documented health disparity, the literature on $\mathrm{OC}$ is still in its infancy. However, we need to remind ourselves that $\mathrm{OC}$ is the most lethal gynecological malignancy. It's about time that more sincere efforts are made to better understand and target $\mathrm{OC}$ health disparities, so that the dismal screening and outcome can be substantially improved.

\begin{abstract}
Abbreviations
AA: African American; BCAT1: Branched chain amino-acid transaminase 1; BMI: Body mass index; CA: Caucasian American; CDKIs: Cyclin dependent kinase inhibitors; CYP2E1: Cytochrome P450 family 2 subfamily E member 1 ; DNMT1: DNA methyltransferase-1; GSTM1: Glutathione s-transferase Mu 1; GSTT1: Glutathione s-transferase theta-1; miRNA: MicroRNA; OC: Ovarian cancer; OS: Overall survival; PFS: Progression free survival; PSPHL: Phosphoserine phosphatase like; SES: Socioeconomic status; TGFBR1: Transforming growth factor beta receptor 1; TUSC3: Tumor suppressor candidate 3
\end{abstract}

\section{Acknowledgements}

Not Applicable.

\section{Funding}

Authors acknowledge the funding support from NIH/NCI [CA185490 (APS), CA204801 (SS) and SBIR contract funding HHSN261201600039C (SKS)] and USAMCI.

\section{Availability of data and materials}

Not Applicable.

\section{Authors' contributions}

SKS, AA, OM and GKP wrote the manuscript; SS, RPR and APS proofread and corrected it; SKS, AA and GKP prepared figures and table; APS conceptualized the idea, provided resources and supervised the project. All authors read and approved the final manuscript.

\section{Authors' information}

SKS, AA, SS, RPR and APS are part of Health Disparities in Cancer Research Program at the University of South Alabama's Mitchell Cancer Institute.

\section{Ethics approval and consent to participate}

Not Applicable.

\section{Consent for publication}

All authors agree to the submission of this article for publication.

\section{Competing interests}

APS and SS are co-founders and serve on executive management board of Tatva Biosciences LLC, a small business involved in the development of tools and models for cancer health disparity research among other things. SKS serves as the Director of Cell Biology and Genetics at Tatva Biosciences LLC.

\section{Publisher's Note}

Springer Nature remains neutral with regard to jurisdictional claims in published maps and institutional affiliations.

\section{Author details}

${ }^{1}$ Department of Oncologic Sciences, Mitchell Cancer Institute, University of South Alabama, 1660 Springhill Avenue, Mobile, AL 36604-1405, USA. ${ }^{2}$ Division of Cell Biology and Genetics, Tatva Biosciences, Coastal Innovation Hub, 600 Clinic Drive, Mobile, AL 36688, USA. ${ }^{3}$ Department of Biochemistry and Molecular Biology, College of Medicine, University of South Alabama,
Mobile, AL 36688, USA. ${ }^{4}$ Division of Gynecologic Oncology, Mitchell Cancer Institute, University of South Alabama, Mobile, AL 36604, USA.

Received: 7 August 2017 Accepted: 1 September 2017

Published online: 21 September 2017

\section{References}

1. Siegel RL, Miller KD, Jemal A. Cancer statistics, 2017. CA Cancer J Clin. 2017;67:7-30.

2. Coburn SB, Bray F, Sherman ME, Trabert B. International patterns and trends in ovarian cancer incidence, overall and by histologic subtype. Int J Cancer. 2017; 140:2451-60

3. Randall TC, Armstrong K. Health care disparities in hereditary ovarian cancer: are we reaching the underserved population? Curr Treat Options in Oncol. 2016;17:39.

4. Rauh-Hain JA, Krivak TC, Del Carmen MG, Olawaiye AB. Ovarian cancer screening and early detection in the general population. Rev Obstet Gynecol. 2011:4:15-21.

5. Collins Y, Holcomb K, Chapman-Davis E, Khabele D, Farley JH. Gynecologic cancer disparities: a report from the health disparities taskforce of the Society of Gynecologic Oncology. Gynecol Oncol. 2014;133:353-61.

6. Chornokur G, Amankwah EK, Schildkraut JM, Phelan CM. Global ovarian cancer health disparities. Gynecol Oncol. 2013;129:258-64.

7. Long B, Chang J, Ziogas A, Tewari KS, Anton-Culver H, Bristow RE. Impact of race, socioeconomic status, and the health care system on the treatment of advanced-stage ovarian cancer in California. Am J Obstet Gynecol. 2015; 212(468):e461-9.

8. Scalici J, Finan MA, Black J, Harmon MD, Nicolson W, Lankes HA, Brady WE, Rocconi RP. Minority participation in gynecologic oncology group (GOG) studies. Gynecol Oncol. 2015;138:441-4.

9. Farley J, Risinger Jl, Rose GS, Maxwell GL. Racial disparities in blacks with gynecologic cancers. Cancer. 2007;110:234-43.

10. Bandera EV, Lee VS, Rodriguez-Rodriguez L, Powell CB, Kushi LH. Racial/ ethnic disparities in ovarian cancer treatment and survival. Clin Cancer Res. 2016:22:5909-14.

11. Rocconi RP, Matthews KS, Kemper MK, Hoskins KE, Huh WK, Straughn JM Jr. The timing of normalization of CA-125 levels during primary chemotherapy is predictive of survival in patients with epithelial ovarian cancer. Gynecol Oncol. 2009;114:242-5.

12. Chan JK, Zhang M, Hu JM, Shin JY, Osann K, Kapp DS. Racial disparities in surgical treatment and survival of epithelial ovarian cancer in United States. J Surg Oncol. 2008;97:103-7.

13. Peres LC, Moorman PG, Alberg AJ, Bandera EV, Barnholtz-Sloan J, Bondy M, Cote ML, Funkhouser E, Peters ES, Schwartz AG, Terry PD, Abbott SE, Camacho F, Wang F, Schildkraut JM. Lifetime number of ovulatory cycles and epithelial ovarian cancer risk in African American women. Cancer Causes Control. 2017;28:405-14.

14. Terry PD, Qin B, Camacho F, Moorman PG, Alberg AJ, Barnholtz-Sloan JS, Bondy M, Cote ML, Funkhouser E, Guertin KA, Peters ES, Schwartz AG, Schildkraut JM, Bandera EV. Supplemental Selenium May Decrease Ovarian Cancer Risk in African-American Women. J Nutr. 2017;147:621-27.

15. Moorman PG, Alberg AJ, Bandera EV, Barnholtz-Sloan J, Bondy M, Cote ML, Funkhouser E, Peters ES, Schwartz AG, Terry P, Crankshaw S, Wang F, Schildkraut JM. Reproductive factors and ovarian cancer risk in AfricanAmerican women. Ann Epidemiol. 2016;26:654-62.

16. Qin B, Moorman PG, Alberg AJ, Barnholtz-Sloan JS, Bondy M, Cote ML, Funkhouser E, Peters ES, Schwartz AG, Terry P, Schildkraut JM, Bandera EV. Dietary carbohydrate intake, glycaemic load, glycaemic index and ovarian cancer risk in African-American women. Br J Nutr. 2016;115:694-702.

17. Brewer KC, Peterson CE, Davis FG, Hoskins K, Pauls H, Joslin CE. The influence of neighborhood socioeconomic status and race on survival from ovarian cancer: a population-based analysis of Cook County, Illinois. Ann Epidemiol. 2015;25:556-63.

18. Peterson CE, Rauscher GH, Johnson TP, Kirschner CV, Freels S, Barrett RE, Kim S, Fitzgibbon ML, Joslin CE, Davis FG. The effect of neighborhood disadvantage on the racial disparity in ovarian cancer-specific survival in a large hospital-based study in cook county, illinois. Front Public Health. 2015;3:8.

19. Joslin CE, Brewer KC, Davis FG, Hoskins K, Peterson CE, Pauls HA. The effect of neighborhood-level socioeconomic status on racial differences in ovarian 
cancer treatment in a population-based analysis in Chicago. Gynecol Oncol. 2014;135:285-91.

20. Terplan M, Schluterman N, McNamara EJ, Tracy JK, Temkin SM. Have racial disparities in ovarian cancer increased over time? An analysis of SEER data. Gynecol Oncol. 2012;125:19-24.

21. Ross J, Braswell KV, da Silva LM, Mujica F, Stutsman S, Finan MA, Nicolson W, Harmon MD, Missanelli M, Cohen A, Singh A, Scalici JM, Rocconi RP. Unraveling the etiology of ovarian cancer racial disparity in the deep south: Is it nature or nurture?. Gynecol Oncol. 2017;145:329-33.

22. Beckmeyer-Borowko AB, Peterson CE, Brewer KC, Otoo MA, Davis FG, Hoskins KF, Joslin CE. The effect of time on racial differences in epithelial ovarian cancer (OVCA) diagnosis stage, overall and by histologic subtypes: a study of the National Cancer Database. Cancer Causes Control. 2016;27:1261-71.

23. Farley JH, Tian C, Rose GS, Brown CL, Birrer M, Maxwell GL. Race does not impact outcome for advanced ovarian cancer patients treated with cisplatin/paclitaxel: an analysis of gynecologic oncology group trials. Cancer. 2009;115:4210-7.

24. Howell EA, Egorova N, Hayes MP, Wisnivesky J, Franco R, Bickell N. Racial disparities in the treatment of advanced epithelial ovarian cancer. Obstet Gynecol. 2013;122:1025-32.

25. Bristow RE, Chang J, Ziogas A, Anton-Culver H, Vieira VM. Spatial analysis of adherence to treatment guidelines for advanced-stage ovarian cancer and the impact of race and socioeconomic status. Gynecol Oncol. 2014;134:60-7.

26. Liu FW, Randall LM, Tewari KS, Bristow RE. Racial disparities and patterns of ovarian cancer surgical care in California. Gynecol Oncol. 2014;132:221-6.

27. Bandera EV, Qin B, Moorman PG, Alberg AJ, Barnholtz-Sloan JS, Bondy M, Cote ML, Funkhouser E, Peters ES, Schwartz AG, Terry P, Schildkraut JM. Obesity, weight gain, and ovarian cancer risk in African American women. Int J Cancer. 2016;139:593-600.

28. Sutherland ME. Overweight and obesity among African American women. J Black Stud. 2013;44:846-69.

29. Erondu CO, Alberg AJ, Bandera EV, Barnholtz-Sloan J, Bondy M, Cote ML, Funkhouser E, Peters E, Schwartz AG, Terry PD, Wallace K, Akushevich L, Wang F, Crankshaw S, Berchuck A, Schildkraut JM, Moorman PG. The association between body mass index and presenting symptoms in African American women with ovarian cancer. J Women's Health. 2002;25(2016):571-8.

30. Liu Z, Zhang TT, Zhao JJ, Qi SF, Du P, Liu DW, Tian QB. The association between overweight, obesity and ovarian cancer: a meta-analysis. Jpn J Clin Oncol. 2015;45:1107-15.

31. Chatterjee S, Gupta D, Caputo TA, Holcomb K. Disparities in Gynecological Malignancies. Front Oncol. 2016;6:36.

32. Allard JE, Chandramouli GV, Stagliano K, Hood BL, Litzi T, Shoji Y, Boyd J, Berchuck A, Conrads TP, Maxwell GL, Risinger II. Analysis of PSPHL as a candidate gene influencing the racial disparity in endometrial cancer. Front Oncol. 2012;2:65.

33. Rummel S, Penatzer CE, Shriver CD, Ellsworth RE. PSPHL and breast cancer in African American women: causative gene or population stratification? BMC Genet. 2014;15:38.

34. Deshmukh SK, Srivastava SK, Tyagi N, Ahmad A, Singh AP, Ghadhban AA, Dyess DL, Carter JE, Dugger K, Singh S. Emerging evidence for the role of differential tumor microenvironment in breast cancer racial disparity: a closer look at the surroundings. Carcinogenesis. 2017;38:757-65.

35. Ahmad A, Azim S, Zubair H, Khan MA, Singh S, Carter JE, Rocconi RP, Singh AP. Epigenetic basis of cancer health disparities: looking beyond genetic differences. Biochim Biophys Acta. 2017;1868:16-28.

36. Scherr CL, Bomboka L, Nelson A, Pal T, Vadaparampil ST. Tracking the dissemination of a culturally targeted brochure to promote awareness of hereditary breast and ovarian cancer among Black women. Patient Educ Couns. 2016;100:805-11.

37. Pal T, Bonner D, Cragun D, Monteiro AN, Phelan C, Servais L, Kim J, Narod SA, Akbari MR, Vadaparampil ST. A high frequency of BRCA mutations in young black women with breast cancer residing in Florida. Cancer. 2015;121:4173-80.

38. Antoniou A, Pharoah PD, Narod S, Risch HA, Eyfjord JE, Hopper JL, Loman N, Olsson H, Johannsson O, Borg A, Pasini B, Radice P, Manoukian S, Eccles DM, Tang N, Olah E, Anton-Culver H, Warner E, Lubinski J, Gronwald J, Gorski B, Tulinius H, Thorlacius S, Eerola H, Nevanlinna H, Syrjakoski K, Kallioniemi OP, Thompson D, Evans C, Peto J, Lalloo F, Evans DG, Easton DF. Average risks of breast and ovarian cancer associated with BRCA1 or BRCA2 mutations detected in case series unselected for family history: a combined analysis of 22 studies. Am J Hum Genet. 2003;72:1117-30.

39. Ahmad A, Banerjee S, Wang Z, Kong D, Majumdar AP, Sarkar FH. Aging and inflammation: etiological culprits of cancer. Curr Aging Sci. 2009;2:174-86.

40. Peres LC, Bandera EV, Qin B, Guertin KA, Shivappa N, Hebert JR, Abbott SE, Alberg AJ, Barnholtz-Sloan J, Bondy M, Cote ML, Funkhouser E, Moorman PG, Peters ES, Schwartz AG, Terry PD, Camacho F, Wang F, Schildkraut JM. Dietary inflammatory index and risk of epithelial ovarian cancer in African American women. Int J Cancer. 2017;140:535-43.

41. Kisielewski R, Tolwinska A, Mazurek A, Laudanski P. Inflammation and ovarian cancer-current views. Ginekol Pol. 2013;84:293-7.

42. Maccio A, Madeddu C. Inflammation and ovarian cancer. Cytokine. 2012;58:133-47.

43. Peres LC, Camacho F, Abbott SE, Alberg AJ, Bandera EV, Barnholtz-Sloan J, Bondy M, Cote ML, Crankshaw S, Funkhouser E, Moorman PG, Peters ES, Schwartz AG, Terry P, Wang F, Schildkraut JM. Analgesic medication use and risk of epithelial ovarian cancer in African American women. $\mathrm{Br} J$ Cancer. 2016;114:819-25.

44. Grant WB, Peiris AN. Differences in vitamin D status may account for unexplained disparities in cancer survival rates between African and white Americans. Dermatoendocrinol. 2012;4:85-94.

45. Lappe JM, Travers-Gustafson D, Davies KM, Recker RR, Heaney RP. Vitamin D and calcium supplementation reduces cancer risk: results of a randomized trial. Am J Clin Nutr. 2007;85:1586-91.

46. Bakhru A, Mallinger JB, Buckanovich RJ, Griggs JJ. Casting light on 25hydroxyvitamin D deficiency in ovarian cancer: a study from the NHANES. Gynecol Oncol. 2010;119:314-8.

47. Chakraborti CK. Vitamin D as a promising anticancer agent, Indian. J Pharmacol. 2011:43:113-20.

48. Audo I, Darjatmoko SR, Schlamp CL, Lokken JM, Lindstrom MJ, Albert DM, Nickells RW. Vitamin D analogues increase p53, p21, and apoptosis in a xenograft model of human retinoblastoma. Invest Ophthalmol Vis Sci. 2003; 44:4192-9.

49. Grant DJ, Hoyo C, Akushevich L, Iversen ES, Whitaker R, Marks J, Berchuck A, Schildkraut JM. Vitamin D receptor (VDR) polymorphisms and risk of ovarian cancer in Caucasian and African American women. Gynecol Oncol. 2013;129:173-8.

50. Schildkraut JM, Murphy SK, Palmieri RT, Iversen E, Moorman PG, Huang Z, Halabi S, Calingaert B, Gusberg A, Marks JR, Berchuck A. Trinucleotide repeat polymorphisms in the androgen receptor gene and risk of ovarian cancer. Cancer Epidemiol Biomarkers Prev. 2007;16:473-80.

51. Buller RE, Sood A, Fullenkamp C, Sorosky J, Powills K, Anderson B. The influence of the p53 codon 72 polymorphism on ovarian carcinogenesis and prognosis. Cancer Gene Ther. 1997;4:239-45.

52. Spillman MA, Schildkraut JM, Halabi S, Moorman P, Calingaert B, Bentley RC, Marks JR, Murphy S, Berchuck A. Transforming growth factor beta receptor I polyalanine repeat polymorphism does not increase ovarian cancer risk. Gynecol Oncol. 2005;97:543-9.

53. Tomar T, de Jong S, Alkema NG, Hoekman RL, Meersma GJ, Klip HG, van der Zee AG, Wisman GB. Genome-wide methylation profiling of ovarian cancer patient-derived xenografts treated with the demethylating agent decitabine identifies novel epigenetically regulated genes and pathways. Genome Med. 2016;8:107.

54. Powell MA, Mutch DG, Rader JS, Herzog TJ, Huang TH, Goodfellow PJ. Ribosomal DNA methylation in patients with endometrial carcinoma: an independent prognostic marker. Cancer. 2002;94:2941-52.

55. Pils D, Horak P, Vanhara P, Anees M, Petz M, Alfanz A, Gugerell A, Wittinger M, Gleiss A, Auner V, Tong D, Zeillinger R, Braicu El, Sehouli J, Krainer M. Methylation status of TUSC3 is a prognostic factor in ovarian cancer. Cancer. 2013;119:946-54.

56. Conway K, Edmiston SN, Tse CK, Bryant C, Kuan PF, Hair BY, Parrish EA, May R, Swift-Scanlan T. Racial variation in breast tumor promoter methylation in the Carolina breast cancer study. Cancer Epidemiol Biomarkers Prev. 2015;24:921-30.

57. Socha MJ, Said N, Dai Y, Kwong J, Ramalingam P, Trieu V, Desai N, Mok SC, Motamed K. Aberrant promoter methylation of SPARC in ovarian cancer. Neoplasia. 2009;11:126-35.

58. Said N, Frierson HF, Sanchez-Carbayo M, Brekken RA, Theodorescu D. Loss of SPARC in bladder cancer enhances carcinogenesis and progression. J Clin Invest. 2013;123:751-66. 
59. Sharma S, Xing F, Liu Y, Wu K, Said N, Pochampally R, Shiozawa Y, Lin HK, Balaji KC, Watabe K. Secreted protein acidic and rich in Cysteine (SPARC) mediates metastatic dormancy of prostate cancer in bone. J Biol Chem. 2016;291:19351-63.

60. Wang ZQ, Faddaoui A, Bachvarova M, Plante M, Gregoire J, Renaud MC, Sebastianelli A, Guillemette C, Gobeil S, Macdonald E, Vanderhyden B, Bachvarov D. BCAT1 Expression associates with ovarian cancer progression: possible implications in altered disease metabolism. Oncotarget. 2015;6:31522-43.

61. Keita M, Wang ZQ, Pelletier JF, Bachvarova M, Plante M, Gregoire J, Renaud MC, Mes-Masson AM, Paquet ER, Bachvarov D. Global methylation profiling in serous ovarian cancer is indicative for distinct aberrant DNA methylation signatures associated with tumor aggressiveness and disease progression. Gynecol Oncol. 2013;128:356-63.

62. Srivastava SK, Ahmad A, Zubair H, Miree O, Singh S, Rocconi RP, Scalici J, Singh AP. MicroRNAs in gynecological cancers: small molecules with big implications. Cancer Lett.

63. Xiang $Y$, Ma N, Wang D, Zhang $Y$, Zhou J, Wu G, Zhao R, Huang H, Wang X, Qiao Y, Li F, Han D, Wang L, Zhang G, Gao X. MiR-152 and miR-185 cocontribute to ovarian cancer cells cisplatin sensitivity by targeting DNMT1 directly: a novel epigenetic therapy independent of decitabine. Oncogene. 2014;33:378-86

64. Theodore SC, Davis M, Zhao F, Wang H, Chen D, Rhim J, Dean-Colomb W, Turner T, Ji W, Zeng G, Grizzle W, Yates C. MicroRNA profiling of novel African American and Caucasian prostate cancer cell lines reveals a reciprocal regulatory relationship of miR-152 and DNA methyltranferase 1. Oncotarget. 2014;5:3512-25.

65. Pearce CL, Rossing MA, Lee AW, Ness RB, Webb PM, S. for Australian Cancer, G. Australian Ovarian Cancer Study, Chenevix-Trench G, Jordan SM, Stram DA, Chang-Claude J, Hein R, Nickels S, Lurie G, Thompson PJ, Carney ME, Goodman MT, Moysich K, Hogdall E, Jensen A, Goode EL, Fridley BL, Cunningham JM, Vierkant RA, Weber RP, Ziogas A, Anton-Culver H, Gayther SA, Gentry-Maharaj A, Menon U, Ramus SJ, Brinton L, Wentzensen N, Lissowska J, Garcia-Closas M, Massuger LF, Kiemeney LA, Van Altena AM Aben KK, Berchuck A, Doherty JA, Iversen E, McGuire V, Moorman PG, Pharoah P, Pike MC, Risch H, Sieh W, Stram DO, Terry KL, Whittemore A, Wu AH, Schildkraut JM, Kjaer SK. C. Ovarian cancer association, combined and interactive effects of environmental and GWAS-identified risk factors in ovarian cancer. Cancer Epidemiol Biomarkers Prev. 2013;22:880-90.

66. Salehi F, Dunfield L, Phillips KP, Krewski D, Vanderhyden BC. Risk factors for ovarian cancer: an overview with emphasis on hormonal factors. J Toxicol Environ Health B Crit Rev. 2008;11:301-21.

67. Langseth $\mathrm{H}$, Kjaerheim K. Ovarian cancer and occupational exposure among pulp and paper employees in Norway. Scand J Work Environ Health. 2004;30:356-61.

68. Shen N, Weiderpass E, Antilla A, Goldberg MS, Vasama-Neuvonen KM, Boffetta P, Vainio HU, Partanen TJ. Epidemiology of occupational and environmental risk factors related to ovarian cancer. Scand J Work Environ Health. 1998;24:175-82

69. Basu Dev B, Tusha S. Gene-Environment Interaction and Risk of Ovarian Cancer. Reproductive System \& Sexual Disorders. 2014;3.

70. Inoue-Choi M, Weyer PJ, Jones RR, Booth BJ, Cantor KP, Robien K, Ward MH. Atrazine in public water supplies and risk of ovarian cancer among postmenopausal women in the lowa Women's health study. Occup Environ Med. 2016;73:582-7.

71. Albanito L, Lappano R, Madeo A, Chimento A, Prossnitz ER, Cappello AR, Dolce $V$, Abonante S, Pezzi V, Maggiolini M. Effects of atrazine on estrogen receptor alpha- and $\mathrm{G}$ protein-coupled receptor 30-mediated signaling and proliferation in cancer cells and cancer-associated fibroblasts. Environ Health Perspect. 2015;123:493-9.

72. Inoue-Choi M, Jones RR, Anderson KE, Cantor KP, Cerhan JR, Krasner S, Robien K, Weyer PJ, Ward MH. Nitrate and nitrite ingestion and risk of ovarian cancer among postmenopausal women in lowa. Int J Cancer. 2015:137:173-82.

73. Ward MH. Too much of a good thing? Nitrate from nitrogen fertilizers and cancer. Rev Environ Health. 2009;24:357-63.

74. Narod SA. Talc and ovarian cancer. Gynecol Oncol. 2016;141:410-2.

75. Terry KL, Karageorgi S, Shvetsov YB, Merritt MA, Lurie G, Thompson PJ, Carney ME, Weber RP, Akushevich L, Lo-Ciganic WH, Cushing-Haugen K, Sieh W, Moysich K, Doherty JA, Nagle CM, Berchuck A, Pearce CL, Pike M, Ness RB, Webb PM, Rossing MA, Schildkraut J, Risch H, Goodman MT.
Genital powder use and risk of ovarian cancer: a pooled analysis of 8,525 cases and 9,859 controls. Cancer Prev Res (Phila). 2013;6:811-21.

76. Houghton SC, Reeves KW, Hankinson SE, Crawford L, Lane D, WactawskiWende J, Thomson CA, Ockene JK, Sturgeon SR. Perineal powder use and risk of ovarian cancer. Journal of the National Cancer Institute. 2014;106.

77. Gonzalez NL, O'Brien KM, D'Aloisio AA, Sandler DP, Weinberg CR. Douching, talc use, and risk of ovarian cancer. Epidemiology. 2016;27:797-802.

78. Berge W, Mundt K, Luu H, Boffetta P. Genital use of talc and risk of ovarian cancer: a meta-analysis. Eur J Cancer Prev. 2017;

79. Cramer DW, Vitonis AF, Terry KL, Welch WR, Titus LJ. The association between talc use and ovarian cancer: a retrospective case-control study in two US states. Epidemiology. 2016;27:334-46.

80. Muscat JE, Huncharek MS. Perineal talc use and ovarian cancer: a critical review. Eur J Cancer Prev. 2008;17:139-46.

81. Gates MA, Tworoger SS, Terry KL, Titus-Ernstoff L, Rosner B, De Vivo I, Cramer DW, Hankinson SE. Talc use, variants of the GSTM1, GSTT1, and NAT2 genes, and risk of epithelial ovarian cancer. Cancer Epidemiol Biomarkers Prev. 2008;17:2436-44.

82. Hayes JD, Flanagan JU, Jowsey IR. Glutathione transferases. Annu Rev Pharmacol Toxicol. 2005;45:51-88.

83. Bristow RE, Chang J, Ziogas A, Randall LM, Anton-Culver H. High-volume ovarian cancer care: survival impact and disparities in access for advancedstage disease. Gynecol Oncol. 2014;132:403-10.

84. Allford A, Qureshi N, Barwell J, Lewis C, Kai J. What hinders minority ethnic access to cancer genetics services and what may help? Eur J Hum Genet. 2014;22:866-74

85. Brannon Traxler L, Martin ML, Kerber AS, Bellcross CA, Crane BE, Green V, Matthews R, Paris NM, Gabram SG. Implementing a screening tool for identifying patients at risk for hereditary breast and ovarian cancer: a statewide initiative. Ann Surg Oncol. 2014;21:3342-7.

86. Schildkraut JM, Abbott SE, Alberg AJ, Bandera EV, Barnholtz-Sloan JS, Bondy ML, Cote ML, Funkhouser E, Peres LC, Peters ES, Schwartz AG, Terry P, Crankshaw S, Camacho F, Wang F, Moorman PG. Association between body powder use and ovarian cancer: the African American cancer epidemiology study (AACES). Cancer Epidemiol Biomarkers Prev. 2016;25:1411-7

\section{Submit your next manuscript to BioMed Central and we will help you at every step:}

- We accept pre-submission inquiries

- Our selector tool helps you to find the most relevant journal

- We provide round the clock customer support

- Convenient online submission

- Thorough peer review

- Inclusion in PubMed and all major indexing services

- Maximum visibility for your research

Submit your manuscript at www.biomedcentral.com/submit
Biomed Central 